\title{
Reconstruction of Legal Culture in the Recovery of Madura and Malay Ethnic Conflict in Sambas District Based on Justice Value
}

\author{
Karman $^{1 *}$, Gunarto ${ }^{2}$, Maryanto ${ }^{2}$, Ngadino ${ }^{2}$
}

${ }^{1}$ Doctorate Student of Faculty of Law Sultan Agung Islamic University Semarang, Indonesia

${ }^{2}$ Faculty of Law Sultan Agung Islamic University Semarang, Indonesia

\begin{abstract}
DOI: $10.36348 /$ sijlcj.2020.v03i11.002
| Received: 17.10.2020 | Accepted: 03.11.2020 | Published: 06.11.2020
\end{abstract}

*Corresponding author: Karman

\section{Abstract}

The strong hope of realizing a just, advanced, and prosperous Sambas community is an ideal that has been embedded for a long time, especially after the Madurese and Malay Ethnic Conflict in Sambas Regency in 1999. In an effort to help realize this goal, the writer feels the needs to conduct research on this subject matter with the main problem discussed in this article that are divided in to what factors that cause inter-ethnic conflict in Sambas and to then analyze the new construction of the legal culture of the society that was developed by the Madurese and Sambas Malay ethnicities in order to further increase the conflict recovery based on the value of justice. This study uses a constructivism paradigm with a socio-legal research approach. The results showed that the ethnocentric and exclusive attitude of the Madurese ethnic group made social interactions with the Sambas Malay ethnic destructive, in the form of a social conflict that ended with the expulsion of the Madurese ethnicity from Sambas Regency. This is exacerbated by differences in origins, cultural values as the basis for differences, also due to the ethnocentric and exclusivistic character of the Madurese as a trigger for conflict, and the weak rule of law as a factor that further widens the life gap between the two ethnic groups where in this case, is a new reconstruction of legal culture, that the Madurese ethnic needs to reposition cultural values in the context of adaptation/adjustment, so that they can be accepted back in Sambas Regency, because they are able to adapt socially and adapt, in the form of multiculturalism education for basic education and middle school, Islamic boarding schools, and aculturation in a form of marriages between Madurese and Dayak as the People of Sambas.

Keywords: Reconstruction, Ethnics Conflict, Sambas, Justice Value.

Copyright (C) 2020 The Author(s): This is an open-access article distributed under the terms of the Creative Commons Attribution 4.0 International License (CC BY-NC 4.0) which permits unrestricted use, distribution, and reproduction in any medium for non-commercial use provided the original author and source are credited.

\section{INTRODUCTION}

Among the most serious conflicts that have occurred in Indonesia, the social conflict between the ethnic Sambas Malay ethnic groups and immigrants from the Madurese ethnic groups that occurred in 1999 in Sambas Regency may be one of them. In 2020, the conflict has shifted from open conflict to latent conflict. This is shown even though the open conflict has ended, the conflict between the two ethnic groups is still ongoing, and post-conflict reconciliation has not been successful. The Madurese ethnic community cannot yet be accepted back to live in Sambas Regency.

At the sociological level, efforts to reconcile the two ethnic groups have long been carried out by the two community leaders, but have not found a common ground. Efforts to reconcile the community leaders of the two ethnicities then got a juridical basis in 2012, with the promulgation of Law Number 7 of 2012 concerning Social Conflict Management.

The rejection of the Sambas Malay community was based on their life experiences while living side by side with the Madurese community. As the view of the Sambas community that the social behavior of the Madurese people living in Sambas Regency, is felt to be unsettling and easily causes conflicts with the Sambas Malay community and with other indigenous tribes in West Kalimantan.

Behavior in the form of acts of violence and murder due to self-respect, known as the "Carok" culture of the Madurese ethnicity, tends to be associated with "ango'an poteya tolang, etembang poteya mata" or "it's better to die-white bones, than to bear shame." and other stricter expression such as "tambana todus, mate" (the medicine for shame is death). The character of the Madurese like this is reinforced by the findings of 
Touwen-Bouwsma [1] that "the Madurese and their knife are one, their hands are always ready to grab and cut," they are trained to use all kinds of weapons, but are most skilled at using Clurit (Sickles).

A similar opinion was expressed by De Jonge [2], stating that "if a Madurese is humiliated, he will draw his knife and immediately avenge or wait for another opportunity to do so". Research conducted by experts, the behavior of the Madurese community that triggers conflict with the Malays and Dayak tribes.

In West Kalimantan, conflicts between the Madurese and the Dayak tribes have occurred five times. Disputes that often involve ethnic Madurese as the main actors who face other ethnicities not only occur in West Kalimantan but also occur in East Kalimantan, Central Kalimantan, Pasar Kramat Jati DKI Jakarta, Tangerang, Banten Province, and several other areas. The sources of problems in conflict are also different, but the habit of carrying sharp weapons and using them for violence is the main source.

The character of the Madurese, as stated earlier, may be considered a normal thing in the life of the Madurese people, especially in their home areas. In a society that has the same character, mutual control will occur between members of the community to maintain balance in community life. However, when such character or behavior is carried over to areas with different characteristics and culture of society, especially people who tend to avoid conflict, as in the character of the Melayu Sambas, it will lead to ethnocentrism and arrogance for the immigrant ethnic groups, because they think that the out-group is the ethnic group as coward. This view has prompted the Madurese to consider that there is an opportunity to act as they please in social life, and by itself will cause clashes in society.

Such behavior was often used as the basis for the Madurese ethnic group at that time in resolving conflicts with other tribes in social life in West Kalimantan. Such behavior is also one of the factors triggering open conflict between the Madurese migrant communities and the indigenous people in West Kalimantan, both with the Dayak and Malay ethnicities. As Chang [3] views that the symptom of the spread of indicated behavior is troubling, it is a basic attitude that is difficult, and not wanting to accept and face such differences will change a person to have a conflicted character.

This behavior seems to have dominated the thinking of a group of Madurese when they attacked the Malay community in Parit Setia Village, Jawai District, Sambas Regency. The attack resulted in casualties where many Malays fall victim to the attack. For the attack, the Sambas Malay community did not immediately retaliate. They leave the solution to law enforcement. The attitude of the Sambas Malay community who left the solution to law enforcers is actually viewed differently by the Madurese community. Feeling that he was above the wind after how many days the same thing was done again by a Madurese who boarded a bus stabbing the bus conductor who happened to be a Malay. These two acts were the trigger for the war between these tribes.

Based on this description, it can be understood why the reconciliation process of the two ethnic groups has not gone well. On the one hand, awareness arises from the two ethnic groups to end the conflicting atmosphere through reconciliation, on the other hand, there is concern from the Malay Sambas community about the possibility of the same conflict, such as conflicts between the Madurese and the Dayak tribes that have occurred repeatedly, and the facts shows that the conflict also started by a group of Madurese people, then became widespread into communal conflict.

In the context that has been stated earlier, the law is an important factor in preventing conflict in society. As Bredemeier [4] thought, who saw that one of the functions of law is as an integration mechanism in society, where the law is agreed upon in the life of society and thus the law can theoretically emit values or behavior that are not in accordance with legal norms regulate people's lives. So that in relation to the postsocial unrest reconciliation in Sambas Regency, that one of the efforts needed to create a conducive atmosphere so that reconciliation can run well, is to reconstruct the legal culture of the two ethnicities, so that they behave socially in accordance with applicable laws and have trust and hope in the law to protect their lives and in resolving conflicts that may arise between them.

Based on the above problems above, the authors are interested in discussing them in a study with the following issues:

1. What are the weaknesses of the legal culture of the Madurese and Malay Sambas communities in the recovery of inter-ethnic conflicts?

2. How is the reconstruction of the legal culture developed by the Madurese and Sambas Malay ethnicities in conflict recovery based on the values of justice?

\section{METHOD OF RESEARCH}

The paradigm that is used in the research this is the paradigm of constructivism which is the antithesis of the understanding that lay observation and objectivity in finding a reality or science knowledge [5]. Paradigm also looked at the science of social as an analysis of systematic against Socially Meaningful Action through observation directly and in detail to the problem analyzed. 
The research type used in writing this paper is a qualitative research. Writing aims to provide a description of a society or a certain group of people or a description of a symptom or between two or more symptoms.

Approach method used in this research is Empirical-Juridical [6], which is based on the norms of law and the theory of the existing legal enforceability of a law viewpoint as interpretation.

As for the source of research [7] used in this study are:

1. Primary Data, is data obtained from information and information from respondents directly obtained through interviews and literature studies.

2. Secondary Data, is an indirect source that is able to provide additional and reinforcement of research data. Sources of secondary data in the form of: Primary Legal Material and Secondary Legal Materials and Tertiary Legal Material.

In this study, the author use data collection techniques, namely literature study, interviews and documentation where the researcher is a key instrument that is the researcher himself who plans, collects, and interprets the data. Qualitative data analysis is the process of searching for, and systematically compiling data obtained from interviews, field notes and documentation by organizing data into categories, describing it into units, synthesizing, compiling into patterns, selecting important names and what will be studied and make conclusions.

\section{RESEARCH RESULT AND DISCUSSION Weaknesses of the Legal Culture of the Madurese and Malay Sambas Communities in The Recovery Of Inter-Ethnic Conflicts}

Every individual and group's social life extends to their inter-ethnic life, always forming a collective image which is cultural knowledge, as well as an indicator of the obedience of legal norms and norms to differentiate the rules of life between one ethnic group and another until known as a characteristic of legal culture. The legal culture that develops from each ethnic group underlies the increasingly pluralistic society in Sambas Regency. In Sambas district, the ethnic distribution of Madurese is around 90 thousand people or about 10 percent of the total population of Sambas Regency.

The legal culture of the Madurese ethnic community is based on the reaction and decision to try their luck in Sambas Regency, because it is considered an ideal and effective choice to migrate to Sambas Regency in the context of improving life, and is supported by the values of openness and acceptance of the Sambas community as part of the selection tool which resulted in a decision, until the ethnic Madurese reacted and then settled in Sambas District. The selection tool can be; age, education, and job opportunities. The principle underlying his consideration is that young Madurese and men are considered more ready to try their luck than older people or children, as well as female residents who originally came to this area, apart from coming through the Transmigration Program in the New Order era.

Regarding awareness of the legal culture of the Madurese ethnicity and the Malay community, it can be observed through symbolization. Although these two ethnicities have experienced integration, "a few" of them are still polarized into forms of internalization based on characters that are believed to be the reason for pursuing quality and life goals. Normatively, the educational facilities provided by the government, both formal and informal, as well as non-formal at the Elementary/equivalent level are generally still used by all ethnic groups, but entering the Middle School/equivalent level and for High School/ equivalent levels begin to lead strongly to the desire communities of each ethnicity, especially the Madurese ethnicity, to direct to more specific schools, such as; education that is managed based on a religious vision and is characterized by ethnicity, rather than utilizing public schools provided by the government.

Taking education into the form of state schools prepared by the government based on this research is only used by the Sambas Malay ethnic group, and the Dayak and Chinese ethnic groups who come from the lower-to-middle economic class because in general, the Dayak and Chinese ethnic groups have upward economic freedom and always orienting their children's education in schools that have been prepared by private educational institutions, ie, school management based on a religious (Christian) vision which is considered to have more quality, such as under the auspices of the Foundation and so on.

On the other hand, the Madurese ethnic group is considered to have its own uniqueness. Normatively, the Madurese ethnic community feels comfortable when their children are included in an Islamic boarding school education environment. The only difference is that the Dayak and Chinese ethnicities are that Pesantren (Islamic Boarding School) education is a collaboration of all Madurese ethnic groups from various economic stratifications of their families, even among them there are other ethnicities, such as Malays and Bugis, only their educational orientation prioritizes Islamic deepening of the basic process of general education.

Based on the calculation of the level of education that each ethnic group has in Sambas District, it can be interpreted that adequate education is the most effective means of building legal principles in undergoing dynamic social interactions. Given that the adaptation process is very much influenced by the legal culture and increases shared perceptions and social 
awareness. Therefore, the fluctuation of education levels based on each ethnic group is still worrying for the ethnic Malays and Madurese, thus indicating the impression that the social interaction between the two ethnic groups in Sambas Regency is classified as "good" compared to the social interactions with Chinese and Dayak ethnic because based on the results of the research shows that the two ethnic groups always maintain their caution in making every social contact and social communication between ethnic groups.

The characteristics of the legal culture can also be seen from a work perspective. The ongoing social dynamics of the community in Sambas Regency does not rule out shifts that occur in the socio-economic sector so that it is considered capable of influencing the patterns and characteristics and orientations of all ethnic groups living in this area which is known as the "West Kalimantan's Mecca's Porch." This shift may occur due to the increasingly sharp level of community competition in the pursuit of respect and freedom of economic potential, plus the increasing number of newcomers or migrants to try their luck in Sambas Regency. Given that in this area it is still relatively easy to compete with the original community, namely the Malay Sambas, especially for those who come from the Java and Sumatra regions, especially those from the Madurese ethnicity.

It is still relatively easy to compete in Sambas Regency according to the perspective of the Madurese ethnic group because, throughout this research, it shows that the Sambas Malay ethnicity in terms of work is more oriented to being a government employee because being a government employee is believed to have economic feasibility (income) and certain social protection. Meanwhile, the Madurese ethnic as immigrants have the view that everything that is done regarding the world of work is solely for the benefit of the family, and their job orientation is not merely to become government employees, but to live independently with certain types of work, namely engaged in agriculture or livestock, trade, and transportation.

The fields of work that the Madurese are engaged in are oriented towards meeting the needs of the family, and this does not only include the fulfillment of a decent place to live, as well as adequate food, drink, clothing, and health for all family members but also includes the need to finance various activities. Madurese ethnic customs. Where the Madurese ethnicity in the context of work is actually inseparable from their cultural customs as a form of group identity. The meaning is that in order to carry out cultural events to provide a strong impetus for the Madurese ethnic group to be able to live economically well. The simplest examples of Slametans (Thanksgiving) and Hajj pilgrimages that inspire the spirit to work hard as Hajj is the goal of all work activities of the Madurese ethnic community. Performing this pilgrimage is a form of perfection of the implementation of the Pillars of Islam, but in the social context performing the Hajj in an ethnic community is considered a form of honor and social status.

The identification of Madurese ethnic culture is generally still concentrated on the types of transportation service jobs and ownership of various types of transportation, such as; city buses, rickshaws, and other river crossing services and choose to be traders, or in other words the Madurese ethnic social interactions are more concentrated on forms of business that are transportation in nature. Meanwhile, the Malay ethnic group mostly does jobs with adequate life security orientation, namely as government employees. This is proof that the Malay ethnic group plays a very important role in determining the dynamics of government and social interactions with other ethnicities, considering that until now, occupying positions as state officials still occupy an honorable position [9] in the eyes of the community.

The Madurese ethnic, in seeing their work, is always based on a religious spirit, whether it is shown for themselves even though they are limited to their primordial environment. Most of the informants from the Madurese ethnic group admitted that as Madurese people have a work ethic for their family and religious spirit so that through their primordial ties, they generally live in groups, and this is almost the same as the way of life of the Chinese or known as Chinatown. On the other hand, the Madurese are seen to show a low work ethic, thus their religious spirit if they live outside the Madurese community, as a means of assimilating with other ethnic groups. The Madurese ethnic group like this is familiar with a deep socialization culture, has even been acculturated, and feels that they have found life in peace with their surroundings, are involved in social activities with their neighbors, and various social activities in their environment as most of the Madurese people open a warung (Stall) or shop.

Based on the admission of the Madurese who open a stall or shop they of course must maintain relationships with their consumers, namely neighbors and the people around them. The Madurese community in this context is very aware of the consequences that they have to develop relationships and pay attention to the harmony of the relationship with the environment in which they live. Based on observations in the field, the researchers found that the average Madurese who opened a stall or shop around a pluralistic community settlement was able to establish quite close relationships with the people around them.

Although no definite data have been found regarding the average life expectancy of the Madurese ethnic group in Sambas Regency, based on observations made that the average life expectancy of the Madurese 
ethnicity is higher than the average life expectancy of the Sambas Malay community, because on average Average age 70.3 years. This, as based on the informant's assumption are caused by the fact that the life expectancy of the Madurese ethnicity is strongly influenced by activities in maintaining a pattern of life activities and enjoying the type of work they are engaged in, and the most crucial thing is the ability to maintain a diet, especially with more emphasis on natural foods.

The success of the Madurese ethnic group in building a better life expectancy has not been matched by the ability to increase the level of education. Whereas higher education at least contributes to ethnic groups so that they are not easily instigated and involved in several disputes and conflicts which end up harming many parties.

\section{Reconstruction of the Legal Culture Developed By the Madurese and Sambas Malay Ethnicities in Conflict Recovery Based On the Values of Justice}

Basically, conflict can arise because there are parties who feel that the social and economic situation is unfair or their rights and interests have been harmed. Therefore, they voiced his dissatisfaction openly and made efforts to transform socio-economic injustice into a more just situation. In its efforts to turn injustice into justice, that party may face another party who has been enjoying an unfair situation and who tends to maintain a well-established social and economic situation that benefits his party. Conflicts between those who want change and those who resist change create conflict. If a conflict like this is prevented, it means that it is a precaution against efforts to create a more just socioeconomic situation. Prevention efforts only need to be done so that the parties do not use violence in fighting for change or maintaining an established situation. Thus, a legal and political system is needed to manage conflict so that it does not cause violence. if in a society every conflict is always accompanied by acts of violence it means proving that the legal, political, and social system of the community concerned has failed to carry out its function.

One of the factors at the root of the conflict is the lack of understanding of multiculturalism in Indonesia. Pluralistic Indonesian society needs multicultural policies so that diversity does not become a conflict that is detrimental to the Indonesian nation but becomes an asset and strength of the Indonesian nation. The state and society have an important role to play in raising awareness of the importance of multiculturalism in Indonesia, especially for areas prone to intercultural conflict.

In relation to the Sambas Conflict, the justice that are needed post-conflict recovery can be carried out in three actions, namely: (a) Reconciliation; (b). Rehabilitation; and (c). Reconstruction.
Reconciliation is carried out by involving customary institutions and / or social institutions or social conflict resolution task forces. Customary institutions, in this case, are from both sides, namely the Madurese and the Sambas Malays.

Rehabilitation needs to be done by doing; (a) Psychological recovery of Conflict Victims and protection of vulnerable groups; (b) Restoration of social, economic, cultural, security and order conditions; (c). Improvement and development of the environment and / or areas of peace; (d). Strengthening of just social relations for the welfare of society; (e). Strengthening public policies that encourage the development of environmental and / or peace areas based on community rights; (f). Economic recovery and civil rights, as well as improving government services; (g). Fulfill the specific basic needs of women, children, the elderly, and groups of people with special needs; (h). Fulfillment of reproductive health needs and services for women's groups; (i). Improving child health services, and $\mathbf{J}$ ). Facilitating and mediating the return and recovery of assets of Conflict Victims.

The reconstruction was carried out by: (a). Recovery and improvement of public service functions in post-conflict environments and/or areas; (b). Restoration and provision of access to education, health, and livelihoods; (c). Repair of public facilities and infrastructure in the conflict area; (d). Improvement of various structures and frameworks that cause inequality and injustice, including economic disparities; (e). Repair and provision of service facilities to fulfill the specific basic needs of women, children, elderly people, and groups of people with special needs; (f). Repair and restoration of places of worship.

The impact of the ethnic riots between the Madurese and Malayu Sambas ethnic groups is still felt, especially for the direct victims of the social unrest. According to the author, the violence between ethnic groups needs to be stopped as other ethnic groups need to "reposition" themselves in their social contacts in every ethnic interaction.

One form of "repositioning" oneself is to suppress potential acts of violence that can occur at any time, namely not carrying sharp weapons while traveling except for work needs. Settling disputes between Madurese and other ethnicities - especially the Sambas Malay ethnicity, through "negotiations" rather than by "threatening" or submitting to law enforcement (police) as a form of ethnic awareness in their social interactions.

Repositioning education and ethnic awareness need to be carried out in order to replace the use of violent means with more sympathetic methods. Therefore, it is necessary to have ethnic awareness to work together in order to build unity for the realization 
of the traditional houses of each ethnicity. The repositioning and revitalization of the Madurese ethnic in their interactions with other ethnicities in West Kalimantan through the establishment of the Madura Traditional House to at least reflect the good-will of the Madurese ethnicity in an inter-ethnic interactions. This gives meaning to Madurese ethnic repositioning efforts to reduce the image of Madurese who tend to solve problems by means of violence and exclusivism.

Next, in Questioning about the Carok culture [10] (as a manifestation of the instrument of violence among Madurese Thuggery who comes from a famous figure named Sakera) is considered as Madurese ethnic exclusivism that needs to be repositioned. Given that the enforcement of the Carok culture which is related to the dignity of the Madurese ethnicity as a manifestation of efforts to defend and maintain self-esteem through physical violence must be abandoned in an accommodating ways. Given that the time to build ethnic unity is needed, the reality as shown by the writer above shows that multi-ethnic life in West Kalimantan - apart from in Sambas Regency - looks deep and intimate, because Dayaks, Chinese, Malay, and Madurese can mingle in a healthy and respectful manner, and it is said that many people regard it as a location. or neighborhoods that are prone to crime and prone to crime, such as in North Pontianak District, as the choice of several ethnic Madurese, ex-refugees of the 1999 Sambas Social Riots. Even though the crime rate in this place is pure, and no longer indicates interethnic grudges because Madurese community leaders are quick to act to resolve these problems by deliberation or submit cases legally.

Regarding the increased education and legal awareness of the Madurese ethnicity in its development that ideally is a time for the Madurese to build honesty about their ethnicity based on the perspective of the Madurese ethnicity. on that basis, it is time to put a book on Madura, West Kalimantan, so that the actual information about the ethnic Madura can be obtained factually. So, the character of the Madurese ethnic group that is often seen by people outside the Madurese ethnic group, such as the Madurese before conducting direct social interaction, are characterized by wearing a hat, sarong, shirt, and black, according to them Madurese, besides that they like to carry sharp weapons and are brave. However, they are resilient in earning a living, like to impose their will, like to oppose and easily draw sharp weapons, it will be revealed whether it is true or not, or have a point, but it has experienced persistence along with the increasing level of education and legal awareness [11] of all Madurese ethnicity.

Then, reflecting on the above problems, the reconstruction of a new legal culture for the two ethnic groups is to direct them to obey and believe in the prevailing legal system, especially in resolving conflicts that occur. The reconstruction of the new legal culture can be carried out with three events, namely mixed marriages between the two ethnicities; (2) developing multicultural education; (3) the dispute settlement is resolved through the PN. What needs to be developed by the Madurese ethnic group in particular, and in order to restore the confidence of the Sambas Malay ethnic group after the social conflict in 1999, is to reposition cultural values in the context of adaptation/adjustment. This means that a person or Madurese ethnic group will be accepted back, when able to adapt socially and adapt. The trick is to put tolerance limits on sociocultural activities which are felt to be an act that truly respects societal values, does not violate the law, so that there is an equilibrium in community life in the form of marriage between ethnic Madurese and Melayu of Sambas, multiculturalism education in a formal education/Islamic Boarding School and resolve legal violations to the district court rather than through violence.

\section{CONCLUSION}

1. The weakness of Madurese and Sambas Malay ethnic legal cultures in resolving ethnic conflicts is that in addition to the factors made in their social differences, is also the fact that the law does not work well or the legal system does not work well where the legal culture of the two ethnicities does not lead them to believe on the legal settlement process and not to mention the fact that the interaction between the two ethnic groups also worsened further by the conflict between the Sambas Malay and Madurese ethnic groups.

2. Reconstruction of a new legal culture towards the two ethnic groups that directs them to obey and believe in the prevailing legal system, especially in resolving conflicts that occur. The reconstruction of the new legal culture can be carried out with three events, namely mixed marriages between the two ethnicities; (2) developing multicultural education; (3) the dispute settlement is resolved through the PN. What needs to be developed by the Madurese ethnic group in particular, and in order to restore the confidence of the Sambas Malay ethnic group after the social conflict in 1999, is to reposition cultural values in the context of adaptation/adjustment. This means that a person or Madurese ethnic group will be accepted back if they are able to adapt socially and adjust themselves - well adjusted. The trick is to put tolerance limits on socio-cultural activities which are felt to be an act that truly respects societal values, does not violate the law, so that there is an equilibrium in community life in the form of marriage between ethnic Madurese and Melayu of Sambas, multiculturalism education in education formal/islamic boarding school and to resolve legal violations to the district court rather than through violence. 


\section{REFERENCES}

1. Wiyata, A. L. (2002). Carok; Konflik Kekerasan \& Harga Diri Orang Madura. Lkis Pelangi Aksara.

2. De Hub, J. (1995). Madura dalam Empat Zaman: Pedagang, Perkembangan Ekonomi dan Islam, Jakarta, PT. Gramedia Pustaka Utama, 13.

3. William, C. (2003). Konflik Komunal di Indonesia Saat Ini, Leiden-Jakarta, INIS and PBB. 2003, 27.

4. Podgorecki, A., \& Whelan, C. J. (1987). Pendekatan Sosiologis Terhadap Hukum. Bina Aksara, Jakarta.

5. Faisal. (2010). Menerobos Positivisme Hukum, Rangkang Education, Yogyakarta.

6. Johnny, I. (2005). Teori dan Metodologi Penelitian Hukum Normatif, Bayumedia, Surabaya.
7. Moleong, L. (2002). Metode Penelitian Kualitatif, PT Remaja Rosdakarya, Bandung.

8. Rosyidi, M. I. (2018). Komunikasi Kelompok Dalam Pemberdayaan Masyarakat Kampung Kelbung Pasca Konflik Madura-Sampit. Jurnal Komunikasi, 12(1), 51-62.

9. Sutianti, S. (2020). Dinamka Konflik Antar Etnis Dayak dan Etnis Madura di Samalantan Kalimantan Barat. ijd-demos, 2(1).

10. Ulum, R. (2013). Prospek Pembangunan Masyarakat Pasca Konflik Sambas. Analisa: Journal of Social Science and Religion, 20(1), 2536.

11. Widodo, W., Budoyo, S., \& Pratama, T. G. W. (2018). The role of law politics on creating good governance and clean governance for a freecorruption Indonesia in 2030. The Social Sciences, 13(8), 1307-1311. 